\title{
A DISCOURSE HISTORICAL ANALYSIS ON LOCAL CULTURE IN THE FIRST BOOK TRILOGY "RONGGENG DUKUH PARUK" BY AHMAD TOHARI
}

\author{
Sri Sugiharti \\ Universitas Riau Kepulauan (Unrika) Batam \\ sri@fkip.unrika.ac.id
}

\begin{abstract}
:
The aim of the research is to examine the representation of Javanese local culture in an old text entitled "Ronggeng Dukuh Paruk". Framed generally by CDA (Critical Discourse Analysis) theory and the method of the research is qualitative study, analyzed by using DHA (Discourse Historical Approach's) perspective, involving three levels of analysis (cf Cresswell, 1998; Alwasilah, 2003; Reisigl \& Wodak, 2009; and Wodak \& Meyer eds., 2009). These levels are three dimensions of discourse analysis that include: (1) identification of discourse content/topic; (2) analysis of discourse strategy; and (3) realization of topic and linguistic strategy at lexical/syntactic level (Reisigl \& Wodak, 2009:93). Since the discourse analyzed in this research is on local wisdom of Javanese society especially as in text in the first trilogy book of "Ronggeng Dukuh Paruk", then, the topic of discourse is also about local wisdom and culture in general. Thus, in this study, the analysis of topic of discourse is not undertaken. The examination is focused on observing the five discursive strategies in micro- analysis under DHA, which includes strategies of nomination, predication, argumentation, perspectivation, and mitigation. The discussion also highlights the socio-cultural background of Javanese people in that period to see its influence on the content of the text itself. Thus, the integration of two disciplinaries of historical study and linguistics is well-achieved.
\end{abstract}

Keyword: historical discourse analysis, local culture, first book trilogy "Ronggeng Dukuh Paruk".

\begin{abstract}
Abstrak
Tujuan dari penelitian ini adalah untuk menguji representasi budaya lokal Jawa dalam teks lama berjudul "Ronggeng Dukuh Paruk". Dibingkai secara umum oleh teori CDA (Analisis Wacana Kritis) dan metode penelitian ini adalah studi kualitatif, dianalisis dengan menggunakan perspektif DHA (Pendekatan Wacana Sejarah) dengan melibatkan tiga tingkat analisis (cf Cresswell, 1998; Alwasilah, 2003; Reisigl \& Wodak, 2009; dan Wodak \& Meyer eds., 2009). Level-level ini adalah tiga dimensi analisis wacana yang meliputi: (1) identifikasi konten / topik wacana; (2) analisis strategi wacana; dan (3) realisasi topik dan strategi linguistik pada tingkat leksikal / sintaksis (Reisigl \& Wodak, 2009: 93). Dalam penelitian ini, analisis topik wacana tidak dilakukan. Pemeriksaan difokuskan pada mengamati lima strategi diskursif dalam analisis mikro di bawah DHA, yang mencakup strategi nominasi, predikasi, argumentasi, perspektif, dan mitigasi. Diskusi ini juga menyoroti latar belakang sosial-budaya orang Jawa pada periode itu untuk melihat pengaruhnya terhadap isi teks itu sendiri. Dengan demikian, integrasi dua disiplin ilmu studi sejarah dan linguistik dapat dicapai dengan baik.

Kata kunci: analisis wacana sejarah, budaya lokal, trilogi buku pertama "Ronggeng Dukuh Paruk".
\end{abstract}




\section{INTRODUCTION}

Civilized society is those who appreciate and maintain their heritage which is, then, manifested into a set of local wisdom and local culture. Local culture is commonly used to characterize the experience of everyday life in specific, identifiable localities. It reflects ordinary people's feelings of appropriateness, comfort, and correctnessattributes that define personal preferences and changing tastes. The socio-cultural of Javanese especially in Jatilawang Banyumas in the time the burning forests became victims of the fires caused by political disputes that infiltrated the villages in the period before 1965. Through the trilogy of "Ronggeng Dukuh Paruk" by Ahmad Tohari (two others Lintang Kemukus Dinihari and Jentera Bianglala), he has raised his life following the perspective of people from his immediate environment to the Indonesian literary court.

The first book of this Trilogy by Ahmad Tohari entitled "Ronggeng Dukuh Paruk" where this book has been very famous since several years ago both inside and outside the country, this book proved to have been made novel even made in the form of film. As the name "Trilogy" is a book written by Ahmad Tohari consisting of three titles, the first one of the book have been analyzed entitled "Ronggeng Dukuh Paruk" (which has been made in a novel since 1982), and the other two books are "Lintang Kemukus Dinihari" (1984) and "Jentera Bianglala "(1985). In fact, the book that has been made this novel has been translated into Japanese, Chinese, Dutch and German, and is now in the process of translation into English. As for the film already exist in English with the title "The dancer" which is actually a translation of the novel "Ronggeng Dukuh Paruk". And the term "Ronggeng" outside the area from the originate of the story "Ronggeng Dukuh Paruk" is a skewed or negative term for a woman who is usually a female penai singing in a group of art, from one place to another to earn money to survive. And if one hears the term "Ronggeng" spontaneously in our minds is: "a naughty woman, beautiful, flirtatious, seductive, entertainer, to get the 'saweran', it is a local term of Javanese area especially giving some money as a sign for a kind of loving and happily sense of able to dance together with "Ronggeng" or able to go bad together in a night, and she is the 
woman who can be invited to 'sleep' by anyone who wants her and that is important the person who wants to fuck her is the one who bears "the have". And there are different views in the term "Ronggeng" in the story that is in Dukuh Paruk, Jatilawang, Banyumas. And in the story of this book, novel or film, A Ronggeng is a kind of proudly girl because of to become "A Ronggeng" is difficult, it is not only beautiful, and able to dance fluently but it must be had a grace of God to be "A Ronggeng". And the strange one is if A Ronggeng is belong to be common people, she is belong to everyone, every man, every people at that area, moreover every man able to take her to take a bed together, and this is as a proudly culture. And for women at that area will proud of too if her husband able to take a ronggeng at the time to take a bad together. And everyone who read this book, novel or watched the film will say it was crazy life.

The analytical model proposed by Ruth Wodak and Martin Reisigl (2001) is an analysis of historical discourse and gained much influence from the Frankfurt flow groups, particularly Jurgan Hubermas. Their research is aimed at studying sexism, antisemit, and realism in the media.

A historical perspective in criticizing texts was chosen because Wodak and Reisigl believed that the historical context behind the creation of discourse and depiction of the discourse community had a central role in the meaning of discourse as it was expressed 'the discourse- historical approach views discourse as a form of knowledge and memory '(Wodak 2003: 13; 2008: 6) and it was drawn from the socio-cognitive theory of Teun van Dijk (1984, 1993, 1998).

Discourse according to Wodak always associated with other discourses that have been produced previously. To understand this approach discourse must be understood as something that is related to other discourses and requires the mastery of knowledge that is sociocultural for the user. Discourse Historical Approach can be identified through several characteristics: 1) DHA is an interdisciplinary approach 2) The interdisciplinary nature of DHA encompasses the theoretical aspects, the results of the study, the background of the research team, and the social practices that lie behind the text. 3) This approach is 'problem oriented'. 4) Both the theory and methodology are 'eclectic' meaning the theory and methodology are integrated to understand and explain the object of study, 
5) This study always involves fieldwork and ethnography, 6) This review requires repeated cross-checking between theory and empirical data.

The critical discourse analysis phase of the Wodak model (DHA) as disclosed in 'The Discourse-Historical Approach' (Wodak \& Meyer, 2011: 63-64) includes 3 stages: 1) Finding specific content or topics of specific discourse, 2) infesting discursive strategies and argumentative strategies used, 3) analyzing the realization of the meaning of specific written language in certain contexts. In an effort to sharpen the analysis, Wodak and Meyer (2001: 72-73) proposed 5 (five) questions and a discursive strategy as follows: 1) How are people's names constructed and linguistically referring to whom? 2) What are the characteristics, characters and forms of drawing constructed for them (discourse actors)? 3) With arguments and arguments as to what person or group of people is described by exclusion and inclusion? 4) From what perspective are labeling, drawing and argument presented? 5) Is the delivery of the message clear, intensive / repetitive or disguised?

The DHA approach thus obliges its users to track what has been said or written before by the subject, what legal product / rule or work it has produced, how the coverage of the concerned has been made by the media and what action has been done by the previous one. Of the five questions, there is an intersection between Wodak's critical discourse analysis and image building efforts in Public Relations constructed through attempting to describe a person positively and negatively. In Wodak's terms, this discursive strategy is done through the creation of positive strategies on the self and the negative image in others. In other words, this model is to construct the discursive 'me and them'. Wodak further explores discourse based on 4 (four) aspects: 1) perspectives used by text producers, 2) self-representation strategies, 3) argumentation strategies, and 4) indirectness strategies. While the unit of analysis departs from the clausal analysis.

Local culture is commonly used to characterize the experience of everyday life in specific, identifiable localities. It reflects ordinary people's feelings of appropriateness, comfort, and correctness-attributes that define personal preferences and changing tastes. Thus, the social aspect in this research refers to local culture values of Javanese people that might be contained in the old story of first book trilogy "Ronggeng Dukuh Paruk". This historical text is potential to study through historical approach as well in order to 
have comprehensive discussion. In this respect, the analysis is undertaken by observing the socio-cultural of Javanese people in that era of political disputes that infiltrated the villages in the period before 1965. Through the trilogy of "Ronggeng Dukuh Paruk" by Ahmad Tohari (two others Lintang Kemukus Dinihari and Jentera Bianglala), he has raised his life following the perspective of people from his immediate environment to the Indonesian literary court.

\section{RESEARCH PROBLEM}

There are plenty of old story across Javanese region around several period of the time before 1965 that contain various informations regarding either the history of Javanese people as had been written in the first book of trilogy "Ronggeng Dukuh Paruk" and the government at the time. In this sense, the topic to study is on how Javanese local wisdom and culture reflected in the first book trilogy "Ronggeng Dukuh Paruk" through the use of discursive strategy by exploring the socio-cultural condition of Javanese people reflected in the book note, and the discursive strategy used to represent the value of Javanese local wisdom and culture.

\section{THEORITICAL STUDIES}

The theories used in this study are local wisdom and culture in general, Javanese local culture in particular, and DHA (Discourse Historical Approach) ever since in the level of micro strategy (Renkema, 2004; and Reisigl \& Wodak, 2009) Local culture is commonly used to characterize the experience of everyday life in specific, identifiable localities. It reflects ordinary people's feelings of appropriateness, comfort, and correctness - attributes that define personal preferences and changing tastes. The sociocultural of Javanese especially in the first book of trilogy "Ronggeng Dukuh Paruk" Jatilawang Banyumas had a unique authority and habitual life and it was reflected in the first book trilogy of "Ronggeng Dukuh Paruk" by Ahmad Tohari. Shortly, local wisdom is a process on how knowledge is resulted, stored, applied, managed, and inherited. A.C. Alwasilah et al. (2009) add that local wisdom has the following characteristics: 
experience-based; survive after being used for centuries; adaptable to current culture; united with people's and institution's everyday practice; commonly practiced by individual or society as a whole; dynamic; and related to belief system ( $c f$ Berkes, 1999; Adler, 2002; Dudley, Zogib \& Mansourian, 2005; and Alwasilah et al., 2009).

It covers the way of observing their environment, solving the problems, and validating information. In terms of Javanese especially in the Dukuh Paruk, Jatilawang Banyumas local wisdom and culture, there are three prominent philosophies as the main standard to determine it. This philosophy is based on linguistic and historical meaning. Beside local wisdom and culture, another theory that frames the study is DHA (Discourse Historical Approach). As CDA (Critical Discourse Analiysis) in general, DHA involves three aspects: critic, ideology, and power. The relation between DHA and those aspects is based on M. Reisigl \& R. Wodak (2009:87). DHA embraces a criticality concept that combines three interrelated aspects: textual or discourse criticism; social criticism; and prospective criticism (Reisigl \& Wodak, 2009).

Ideologically, in DHA it is often seen as a view of the world that is composed of mental representations, views, opinions, attitudes, and evaluations, which belong to members of a particular social group (Renkema, 2004; and Reisigl \& Wodak, 2009). Ideology plays an important role in establishing and maintaining differences in power relations through discourse. In terms of power, it is associated with differences in relationships among social actors. In DHA, power is interpreted as a possibility to take someone's power in a social relationship against the power of others (Renkema, 2004; and Reisigl \& Wodak, 2009).

DHA also formulates three dimensions of discourse in constructing reality. They are cognitive, socio-psychological, and linguistic dimensions (Reisigl \& Wodak, 2009). It is these dimensions which are also dismantled when analyzing discourse by means of DHA. In this research, the third level of analysis is conducted to disclose the linguistic and historical values of local wisdom and culture of Javanese people in the first trilogy book Ronggeng Dukuh Paruk. But the cognitive and socio-psychological dimensions are discussed in different forms, since the writer of the text book no longer exist. 
Furthermore, R. Wodak et al. (2009) argue that discourse has four functions: constructive, perpetuation or justification, transformation, and dismantling and destructive of certain social or ideological conditions (Wodak et al., 2009:33). R. Wodak et al., further, call it macro-discourse strategy. In practical analysis in the textual level, the strategies are, then, realized in the form of five micro strategies (Wodak et al., 2009). The strategies include: nomination, predication, argumentation, perspectivation, and intensification or mitigation (Wodak et al., 2009). The nomination strategy serves to show how social actors or things are constructed in discourse. Predication strategy is to show the quality or label of the social actors or the things being constructed. Furthermore, argumentative strategy isto legitimize or deny the ideas/opinions of particular parties or social actors in the discourse. Perspective strategy is used to explain the position of discourse maker. Lastly, strategy of intensification/mitigation is used to alter (add intense or limiting) the act of illocution or discourse ideas (cf Akmajian et al., 1995; Renkema, 2004; Reisigl \& Wodak, 2009; and Wodak et al., 2009).

\section{METHODOLOGY}

This research is a qualitative study from DHA (Discourse Historical Approach)'s perspective, involving three level of analysis ( $c f$ Cresswell, 1998; Alwasilah, 2003; Reisigl \& Wodak, 2009; and Wodak \& Meyer eds., 2009). These levels are three dimensions of discourse analysis that include: (1) identification of discourse content/topic; (2) analysis of discourse strategy; and (3) realization of topic and linguistic strategy at lexical/syntactic level (Reisigl \& Wodak, 2009:93). Since the discourse analyzed in this research is on local wisdom of Javaneses society especially as in text in the first trilogy book of "Ronggeng Dukuh Paruk", then, the topic of discourse is also about local wisdom and culture in general. Thus, in this study, the analysis of topic of discourse is not undertaken.

\section{FINDING AND DISCUSSION}

The story in the first trilogy book contains of local policy and culture which hereditary should not be lost from "Dukuh Paruk" which is where his ancestor known as Ki Secamenggala, where the place has its own policy and culture which is hereditary 
considered as part of the culture that must be preserved and not to be extinct. One of them is "Ronggeng / the dancer", where not all girls can become "a ronggeng", although they have beautiful faces and are good at singing, but that is not enough to be a ronggeng if there is no element of "ancestral incarnation" And at that moment the last ronggeng was died when Srintil was a baby, and now Srintil has grown up and beautiful, and for her to be a ronggeng is a pride for being able to continue the culture of the ancestors of Ki Secamenggala.

At that time, if we look, read a book or watch the movie of Ronggeng Dukuh Paruk and their life, It does not reflected the existence of religion there, where it is depicted has its own life, closed from the outside world and according to the story that their ancestor Ki Secamenggala was the head of the bastards, hooligans group who wants his life not disturbed by anyone, so Ki Secamenggala chose to live in a high mountain, far from the influence of outer life, having offspring, life, policies and rules of his own that need to be preserved by his hereditary children from generation to generation. The habits of "Dukuh Paruk" people, as a grip in his/her life, is a culture that cannot be separated from daily activities.

The daily life of the people is gardening of corn, cassava, and other crops. Because in their life they do not recognize rice as its staple food, the life of its people seems poor, uneducated, even Srintil (a ronggeng who gets the incarnation from the power) and Rasus, a man who is actually Srintil's lover and a friend since a child. But in the life of a ronggeng, there can be no "Love" because a ronggeng is a common property, public property, anyone can have it, so a ronggeng cannot have her own life and love as a girl in general. In the view of the local people being a ronggeng is an honor and pride especially "Dukuh Paruk", menwhile in the opinion of the Javanese community outside the "Dukuh Paruk" in the book "The First Trilogy book of Ronggeng Dukuh Paruk ", a ronggeng is an artist, and she usually has an artist group and able to sing a special song from one place to another, and the word "Ronggeng" is a less respectable woman image, because Ronggeng is a woman who can be slept by the masher, and anyone can give "saweran" to her. Saweran is a local term of giving money to a Ronggeng, and the size of range depends on how capable one is. The higher of the "saweran" the more can get the ronggeng to sleep together. 
Now, "Sang Penari” (The Dancer) is a 2011 Indonesian film based on the trilogy of novels Ronggeng Dukuh Paruk by Ahmad Tohari and directed by Ifa Isfansyah. Starring Nyoman Oka Antara and Prisia Nasution, it tells the story of a young man and his friendship with his small village's new ronggeng.

Nomination strategy, that serves to construct social actors, objects/phenomena/ events, and processes/actions (Wodak et al., 2009) at the same time, shows three human interactions in Javanese philosophy, those are: human relationships with oneself or human beings; human relationships with God; and human relationships with nature (Noorduyn, 1982; Danasasmita et al., 1987; Ekadjati, 1995; Suryalaga, 2002; Zahorka, 2007; and Gunawan, 2013).

Meanwhile, in relation to nature, there is a little number of linguistic instruments recorded in the manuscript. There are only a few clues arise in the element of concrete events in the form of the mention of the phrase "groceries" and "plants". This is related to the economic activity of Javanese people, who dominantly farmed, so that it cannot be separated from activities related to nature (Sekarwulan, 2009; Sudjana \& Hartati, 2011; and Gunawan, 2013).

\section{Conclusion}

The socio-cultural condition of Javanese people at the time at the first trilogy book of "Ronggeng Dukuh Paruk" was produced, which include religious, socioeconomic, and cultural conditions, is precisely captured by the text. Through its discursive strategies, the text presents that the religious life of Javanese people at that time is mostly influenced by Hinduism. In economic side, people of Dukuh Paruk Jatilawang as the story in "The First Trilogy Book of Ronggenga Dukuh Paruk" generally work in farming field. Meanwhile, the cultural condition indicates the pluralistic life of Javanese community.

In terms of linguistic realization through micro strategies that cover nomination, predication, argumentation, perspectivation, and mitigation, the overall strategies support the conformity of the text with the values of the Javanese local wisdom and culture, 
which briefly centers on three relationships: human relationships with fellow human beings, with God, and with nature.

\section{Bibliography}

Noorduyn, J. (1982). "Danasismita et all, 1987; Ekajati 1996; Suralaya 2002; Zahorka, 2007; and Gunawan, 2014.

Reisigl, M. \& R. Wodak. (2009). "The Discourse Historical Approach” in R. Wodak \& M. Meyer [eds]. Methods of Critical Discourse Analysis. London: Sage Publications Ltd., 2nd edition.

Renkema, J. (2004). Introduction to Discourse Studies. Philadelphia, PA: John Benjamins.

Sekarwulan, 2009; Sudjana \& Hartati, 2011; and Gunawan 2013. Wodak \& Meyer, (2001:63-94) The Discourse Historical approach.

Tohari, Ahmad, (1982) The First Trilogy Book of "Ronggeng Dukuh Paruk".

Van Dijk, (1984, 1993, 1998). Sociolinguistics theory.

https://www.youtube.com/watch?v=R2H5cJEkB8I\&t=1290s

https://www.youtube.com/result?research_query=subtitle+the+dancer+dukuh+paruk 